\title{
Biology and Physics, multidisciplinarity in a Cuerpo Académico
}

\section{Biologia y Física, multidisciplinariedad en un Cuerpo Académico}

\author{
APARICIO-FERNÁNDEZ, María del Rayo $\dagger^{*}$, MESA-CORNEJO, Viviana Matilde and MEJÍA- \\ SÁNCHEZ, Jorge Enrique
} Centro Universitario de los Lagos, Universidad de Guadalajara, Enrique Díaz de León 1144, Colonia Paseos de la Montaña,
Lagos de Moreno, Jalisco, México, CP: 47460

ID $1^{\text {st }}$ Author: María Del Rayo, Aparicio-Fernández / ORC ID: 0000-0003-3154-9525, Researcher ID Thomson: S-48962018, CVU CONACYT ID: 201694

ID $1^{\text {st }}$ Coauthor: Viviana Matilde, Mesa-Cornejo / ORC ID: 0000-0002-6983-0243, Researcher ID Thomson: S-5903-2018, CVU CONACYT ID: 31640

ID $2^{\text {nd }}$ Coauthor: Jorge Enrique, Mejía-Sánchez / ORC ID: 0000-0001-6377-8352, Researcher ID Thomson: S-5924-2018, CVU CONACYT ID: 26430

\begin{abstract}
In 1996 it was created in México the Teacher's Improvement Program, PROMEP (so called by its acronym in Spanish), now it called PRODEP. This program was design to make higher the teachers' academic level who was working as fulltime, by organizing them in working groups called Cuerpos Académicos (CAs), this it was done in order to improve their academic and scientific productivity. Educational institutions, specifically universities, implement the CA model and the Universidad de Guadalajara was not the exception. To create a CA it is necessary to take in account specific characteristics, from the areas of knowledge involved, the empathy of the members until the delimitation between personal and group work; but nevertheless, the experience does not end by delimiting the rules to ensure success in the conformation, growth and consolidation of them. This work described the action plan executed to design, shape and implement a multidisciplinary academic CA, under the environmental conditions of a state public university.
\end{abstract}

Academic Corps, multidisciplinary, PRODEP

\begin{abstract}
Resumen
En el año de 1996 se creó en México el Programa de Mejoramiento del Profesorado PROMEP (actualmente PRODEP), diseñado para mejorar el nivel de habilitación del profesorado de tiempo completo, a través del fomento a la organización de los profesores en grupos de trabajo llamados Cuerpos Académicos (CAs), esto con la finalidad de hacer sinergia entre sus integrantes y con ello aumentar la productividad académica y científica de los mismos. Las instituciones educativas, en particular las universidades, implementaron el modelo de CA y la Universidad de Guadalajara no fue la excepción. La creación de un CA contempla características muy precisas, desde las áreas del conocimiento involucradas, la empatía de los integrantes hasta la delimitación entre el trabajo personal y el grupal; sin embargo, la experiencia no termina por delimitar las reglas para asegurar el éxito en la conformación, crecimiento y consolidación de los mismos. En este trabajo se relata el plan de acción ejecutado para diseñar, conformar y poner en marcha un CA académico multidisciplinario, bajo las condiciones ambientales de una universidad pública estatal.
\end{abstract}

Cuerpo Académico, multidisciplinariedad, PRODEP

Citation: APARICIO-FERNÁNDEZ, María del Rayo, MESA-CORNEJO, Viviana Matilde and MEJÍA-SÁNCHEZ, Jorge Enrique. Biology and Physics, multidisciplinarity in a Cuerpo Académico Journal of Systems and Educational Management. 2019. 6-19: 1-4

\footnotetext{
* Correspondence to Author (email: mdevasnik@yahoo.com.mx)

$\uparrow$ Researcher contributing as first author.
} 


\section{Introduction}

What does biology have to do with mathematics or physics? For people unfamiliar with the different areas of knowledge they may seem a little, or not at all, related; however, we must not forget that the separation between disciplines is caused by the human being; In nature, in a phenomenon studied by physics, not only physical processes are present, chemical processes and perhaps even biological processes are also involved. Today the work is multidisciplinary, that is, biologists and mathematicians, chemists and physicists can work together and there are even large work teams in which specialists from all these areas are collaborating at the same time. This work describes the action plan executed to design, shape and implement a multidisciplinary CA, under the environmental conditions of a state public university.

\section{Theoretical framework}

In 1996, the Teacher Improvement Program, PROMEP (currently PRODEP), was created in Mexico, designed to improve the level of qualification of full-time teachers, through the promotion of the organization of teachers in working groups called Academic Bodies (CAs) (http://www.dof.gob.mx/nota_detalle.php?codi go=5289454\&fecha $=28 / 02 / 2013$ ), this with the purpose of making synergy among its members and thereby increasing academic productivity and scientific of them. Educational institutions, particularly universities, implemented the CA model and the University of Guadalajara was no exception.

In 2006 the University Center of the Lakes (CULagos) turned two years as a regional University Center; This center was previously dependent on the University Center of Los Altos (http://www.lagos.udg.mx/acerca/historia) and was made up of two divisions, the Regional Culture Studies Division and the Studies Division of the Biodiversity and Technological Innovation (DEBIT), the authors belong to the latter. At that time, DEBIT had 40 full-time professors recently hired; for this reason.

The administration of the CULagos, through the director of the DEBIT, was given the task of summoning its professors to organize and form CAs. The group of teachers was made without much knowledge about the work performed by the members of each group.
In that first attempt, not all professors found affinity in academic subjects and possibly did not find empathy with their peers, so that several academic bodies formed in this way disintegrated, since in the evaluation of them their members did not present joint work. Thus, in the next call of the then PROMEP, new groups were formed to try, once again, to work as a team.

It is important to mention that the creation of a CA contemplates very precise characteristics, from the areas of knowledge involved, the empathy of the members, to the delimitation between personal and group work.

As a result of the aforementioned attempts, $90 \%$ of the DEBIT teachers' plant was organized in CAs. In 2012 there were still some teachers without belonging to a CA. The administration once again recommended that these professors group together to form an academic body, but experience had shown that grouping by simply belonging to the same discipline was not the way to organize.

\section{Methodology}

Among the remaining professors were a physicist and a biologist who had tried to form, a year earlier, a CA with another biologist, without this attempt working; Therefore, they decided to make the invitation to a teacher with physics training and thus began the multidisciplinary CA protagonist of this story.

The initial work consisted of meetings to know the individual work that each one did, the academic inclinations, the teaching workload of each one, the equipment and the physical space for laboratory with which each one counted, the state in which that one was physical space, the goals and objectives that were had regarding the investigation.

After verifying the affinity of academic interests of the group members, the meetings were dedicated to defining the Lines of Generation or Innovative Application of Knowledge (LGAC) (https://promep.sep.gob.mx/ca1/Conceptos2.ht $\mathrm{ml}$ ) of the new CA, plan the academic work and carry out the pertinent activities to request recognition as CA by PROMEP. The result of all this effort was the recognition of our group as UDG-CA-732, Academic Body in Training (CAEF), in 2013.

APARICIO-FERNÁNDEZ, María del Rayo, MESA-CORNEJO, Viviana Matilde and MEJÍA-SÁNCHEZ, Jorge Enrique. Biology and Physics, multidisciplinarity in a Cuerpo Académico Journal of Systems and Educational Management. 2019 
Communication between the members of a CA is a determining element that undoubtedly contributes to its progress, therefore (and due to the strong academic load that each member has) it is necessary to leave a space of coincidence in the working day to lead to Out of work meetings. On average, this CA dedicates a meeting of three hours per week to define the activities to be carried out: topics to be developed, participation in calls to obtain resources, attendance at conferences, monitoring the work of its student thesis or social service providers, etc. Here it is clear that each member of the CA also works individually or with other colleagues.

When performing the inventory of physical spaces and equipment, it was determined that the two spaces that were held would form an academic unit under the name of the Laboratory of Physics Applied to Biological Systems; one of the spaces would correspond to the Area of Optical Properties of Matter and the other to the Area of Biological Physical Analysis. The physical spaces still required electrical, water and drainage facilities, internet, compressed air, paint on the walls, floor and installation of rock-board to divide the area of Optical Properties.

\section{Results}

At the time of CA's integration, the laboratory equipment available corresponded to the individual management of each of the members; for this reason it was decided to participate in the 2014 Call for Strengthening for CAEFs and with the benefit this request was continued with the laboratory equipment.

In August 2016, the Physical-Biological Analysis laboratory was put into operation. The results that have been obtained from that laboratory they are: a) the training of human resources at the bachelor's degree in Biochemical Engineering, with the early incorporation into scientific research, through the DELFIN program and the program of economic stimuli to outstanding students, in the modality of motivation to research, b ) the development of the research line: genetics of respiratory diseases, in particular, the Genotyping of Alpha-1 Antitrypsin, a unique procedure in the region that provides relevant and timely information on the genetic predisposition to conditions such as COPD and pulmonary emphysema.
Which It is offered as part of the provision of services to the community in general in the field of Health and Social Security of the Catalog of Services and Applied Research, offered by the Coordination of Linking and Social Service of the University of Guadalajara, c) the use of Biological model Drosophila melanogaster (fruit fly) for the aná lysis of behavior patterns dependent on physical variables, such as certain wavelengths of the electromagnetic spectrum, the response to the magnetic field direction and the interaction between them so that they are extrapolated to different biological populations.

In 2018, the administration of the CULagos handed over to the CA the Optical Properties laboratory after an acceptable authorization; since then it has partially operated and it has been able to continue with the following projects: a) Optical properties of Eichhornia crassipes (Water Lily), b) Defluorization of drinking water by activated carbon obtained from Eichhornia crassipes, c) Fluoride distortion by carbon nanostructures In addition, the laboratory has generated human resources through the qualification of a master's student and a student, also a master's degree, next to graduate.

In this year the CA was benefited by the Program for Strengthening Research and Postgraduate (internal call of the UDG); resource that will be used to continue the qualification of the Optical Properties laboratory.

The academic body carries out activities such as the delivery of workshops, organization of symposiums, presentation of work in congresses, monitoring the progress of the thesis students who are developing some topic of the CA and advised by one of its members; all this sticking to their LGACs, which are:

Study of the physical-biological behavior of molecules and organisms.

Mathematical models in biological systems. Disclosure, extension and teaching of the physical-biological sciences. 
Currently, all the members of the CA have a valid PRODEP profile, the publication of articles as a whole has begun and the publication of a dissemination book edited by them has been opened.

UDG-CA-732 has been evaluated on one occasion and has the status of CA in formation. It is planned to continue with the equipment of the laboratory and to bridge the gap between the individual academic subjects of the members of the CA to work in tune in the development of the same subject.

The plans for the near future are to launch the Optical Properties area and complete the equipment of the Physical-Biological Analysis space of the Laboratory, and if so, strengthen the service offered in the Catalog of Services and Applied Research Coordination of Linking and Social Service of the University of Guadalajara, maintaining and maintaining in good condition our biological models to bring the results of their studies to directly impact on society, increase the supply of their services not only to the region but to the national level; As an example of this, we can mention the study of the labor impact of the different lighting sources, propose tools for the defluorization of water in the region and provide timely information on the predisposition to respiratory diseases of different population groups.

\section{Acknowledgments}

The UDG-CA-732 thanks the University of Guadalajara for the support granted through the calls for Strengthening Research and Postgraduate, and PRODEP, through the programs to Strengthen Academic Bodies in Training and support for new Full Time Teachers.

\section{Conclusions}

With almost six years of existence, UDG-CA732 is currently in the status of CA in formation. The progress achieved is satisfactory if all aspects that need to be resolved to obtain resources and services from the institutions that provide support are taken into account.
On the other hand, the consolidation of a $\mathrm{CA}$ is a process that takes several years because it requires the training of human resources, the generation of good quality academic products and the collaboration between the members of the CA reflected in their joint production (https : //promep.sep.gob.mx/ca1/Conceptos2.html). In order to achieve this consolidation, in addition to constant work, it is necessary to address the human aspect of working relationships between members of the CA (support, empathy, tolerance, etc.); in this way it is possible to transform a group that tries to work together in a real work team.

\section{References}

Diario oficial de la federeación, en: http://www.dof.gob.mx/nota_detalle.php?codig $o=5289454 \&$ fech $a=28 / 02 / 2013$

Creación del Centro Universitario de los Lagos en: http://www.lagos.udg.mx/acerca/historia, accesado el 9 de septiembre de 2019.

Dirección de superación académica https://promep.sep.gob.mx/cal/Conceptos $2 . h t m$ l 